\title{
Growth hormone and fertility in oMt1a-oGH transgenic mice
}

\author{
A. D. Thomas ${ }^{1}$, J. D. Murray ${ }^{1,2}$, T. R. Famula ${ }^{1}$ \\ and A. M. Oberbauer ${ }^{1 *}$ \\ ${ }^{1}$ Department of Animal Science, University of California, Davis, CA 95616-8521, USA; and \\ ${ }^{2}$ Department of Population, Health and Reproduction, School of Veterinary Medicine, \\ University of California, Davis, CA 95616-8521, USA
}

\begin{abstract}
Female mice carrying a regulatable growth hormone transgene (oMt1a-oGH) are subfertile when the transgene is actively expressed. This study was designed to characterize subfertility caused by increased concentrations of growth hormone. In particular, this study aimed to: (i) determine the effects of transgene activation and inactivation on mating, conception, maintenance of pregnancy, ovulation rate, litter characteristics and embryonic survival at day 17 of pregnancy, (ii) characterize oestrous cyclicity in transgenic versus wild-type female mice, and (iii) correlate corticosterone concentrations with transgene expression and reproductive performance. Transgenic and wild-type female mice were allocated randomly to one of four treatment groups at weaning: (i) transgenic female mice that always express the transgene, (ii) transgenic female mice that never express the transgene, (iii) transgenic female mice that express the transgene for up to 8 weeks of age and (iv) non-transgenic wild-type female mice receiving the transgene stimulus
\end{abstract}

until 8 weeks of age. Activation followed by inactivation of the transgene resulted in an increased incidence of remating, resulting in an extended interval to establish pregnancy in comparison with all other treatment groups. Transgenic mice that always expressed the transgene and those that expressed the transgene for up to 8 weeks of age had lower pregnancy rates and higher ovulation rates compared with mice from other treatment groups. Both embryonic survival and the duration of the oestrous cycle did not differ among treatment groups. Active expression of the transgene resulted in an increase in the plasma concentration of corticosterone, which was associated with reduced fertility. These data indicate that the presence of a high growth hormone concentration impedes the establishment and maintenance of pregnancy. Increased plasma corticosterone concentrations may interfere with implantation as well as potentiate leptin resistance, which has been reported previously in studies with these mice.

\section{Introduction}

Although heterologous $\mathrm{GH}(\mathrm{GH})$ has been used in livestock to enhance desirable traits for economic purposes (Etherton et al., 1986; Campbell et al., 1989; Chapula and Galligan, 1989; McGuffey et al., 1991a; Stelwagen et al., 1993; Buskirk et al., 1996; Chapula et al., 1996), many studies have demonstrated reduced reproductive performance in cows supplemented with bovine somatotrophin (bST), a synthetic bovine GH (McGuffey et al., 1991b; Downer et al., 1993; Oldenbroek et al., 1993; Esteban et al., 1994; Buskirk et al., 1996; Chapula et al., 1996). In addition, humans with acromegaly, a disorder characterized by high circulating concentrations of $\mathrm{GH}$, display menstrual disorders and impotence (Jadresic et al., 1982). Multiple transgenic mouse lines expressing heterologous $\mathrm{GH}$ also display a variety of reproductive deficits (Bartke et al., 1988; Cecim et al., 1995a,b,c; Murray and Pomp, 1995; Pomp et al., 1995).

The ability to control the ovine metallothionein 1a

*Correspondence

Email: amoberbauer@ucdavis.edu promoter (oMt1a)-ovine $\mathrm{GH}(\mathrm{oGH})$ construct makes it a useful tool for the study of reproduction during developmental periods of interest. The oMt1a promoter, which possesses a low basal expression that does not enhance growth in animals with a non-induced transgene (Shanahan et al., 1989), can be induced by the addition of $\mathrm{ZnSO}_{4}$ to the drinking water, which in turn drives expression of $\mathrm{oGH}$. Oberbauer et al. (1997) reported average plasma oGH concentrations of $2279 \mathrm{ng} \mathrm{ml}^{-1}$ for activated transgenic animals, whereas oGH concentrations for non-induced transgenic mice were only $66 \mathrm{ng} \mathrm{ml}^{-1}$. Pomp et al. (1995) observed that oMt1a-oGH female mice actively expressing the transgene are subfertile, and that failure of early pregnancy is associated with premature regression of the corpus luteum (Murray and Pomp, 1995). In addition, these females display multiple copulatory plugs over a short period of time without showing evidence of pseudopregnancy, indicating failure of pregnancy due to luteal 'insufficiency' (Pomp et al., 1995).

The present experiments were undertaken to elucidate further the effects of $\mathrm{GH}$ on the reproduction of oMt1a-oGH female mice. The first objective of this study was to examine the effects of activation and inactivation of the transgene 
stimulus on the ability of the oMt1a-oGH female mice to conceive and carry pregnancy to term. Assessing the time required to establish and maintain pregnancy after transgene inactivation may provide an additional insight into the mechanism of $\mathrm{GH}$ inhibition on fertility. In addition, alterations in reproductive performance in response to $\mathrm{GH}$ or $\mathrm{GH}$ withdrawal, including ovulation, litter characteristics and embryonic survival as assessed on day 17 of pregnancy were also examined. The study also aimed to correlate oestrous cyclicity with transgene activation and inactivation, and to determine how circulating corticosterone concentrations vary with transgene expression and reproductive performance. Other studies have reported that high concentrations of corticosterone are associated with expression of other $\mathrm{GH}$ constructs (Cecim et al., 1991, 1996) and Cecim et al. (1996) reported a decrease in glucocorticoid secretion from the adrenal glands when they are removed from the high $\mathrm{GH}$ environment. Plasma corticosterone concentrations are of interest because of their ability to suppress oestrous cyclicity (Brann and Mahesh, 1991), LH secretion (Baldwin, 1979; Suter and Schwartz, 1985; Kamel and Kubajak, 1987; Brann and Mahesh, 1991), sexual behaviour (de Catanzaro and Gorzalka, 1980; de Catanzaro et al., 1981a,b; de Catanzaro, 1987) and pregnancy (Spaziani and Szego, 1958; Schlough, 1971).

\section{Materials and Methods}

\section{Animals}

Mice were produced by mating MG101 $\mathrm{H}$ mice in a CCX (C57/BL6 × CBA) background, homozygous for an oMt1aoGH fusion gene (Shanahan et al., 1989), to CCX wild-type mice. The resulting offspring were hemizygous for the oMt1a-oGH construct. At 9-11 days of age, transgenic and wild-type CCX mice (derived from CCX $\times$ CCX crosses) were toe-notched for identification purposes. At 21 days of age, mice were weaned, weighed and separated by genotype, and then housed in groups of 3-7 animals per cage. Mice had ad libitum access to feed (Purina Mouse Chow diet 5001, St Louis, MO) and drinking water. Activation and inactivation of the transgene were achieved by the presence or absence of 25 mmol $\mathrm{ZnSO}_{4} \mathrm{I}^{-1}$ (Sigma Chemical Inc.) in the drinking water, respectively. Removal of the zinc stimulus resulted in a decrease in the circulating $\mathrm{GH}$ concentrations to basal values within $24 \mathrm{~h}$ (Shanahan et al., 1989). Body weights were recorded each week from weaning up to 8 weeks of age for all animals. A greater number of transgenic female mice was assigned to each treatment because of the known variability in reproduction in transgenic female mice.

Animals were housed under conditions of constant day length ( $14 \mathrm{~h}$ light: $10 \mathrm{~h}$ dark), temperature $\left(70^{\circ} \mathrm{F}\right)$ and average humidity (55\%) in an AAALAC-approved laboratory animal colony following NIH guidelines for animal care.

\section{Fertility study}

Results of other studies have demonstrated that few oMt1a-oGH female mice actively expressing the transgene at the time of mating can maintain pregnancy (Murray and Pomp, 1995; Pomp et al., 1995). The time required by transgenic female mice, after transgene inactivation, to establish and maintain pregnancy was determined by allocating at weaning, 56 transgenic and 22 wild-type female mice randomly to one of four treatment groups: (i) transgenic female mice that received zinc supplementation from 3 weeks of age to day 17 of pregnancy (TG ON); (ii) transgenic female mice that did not receive zinc supplementation (TG OFF), (iii) transgenic female mice that receive zinc supplementation from 3 to 8 weeks of age (TG ON/OFF); and (iv) wild-type female mice that received zinc from 3 to 8 weeks of age (WT). At 8 weeks of age, female mice were mated to CD1 males of proven fertility. The females were housed with the males for 14 days, during which time the presence or absence of a vaginal copulatory plug was evaluated each day. The day of mating (day 0) was determined by the presence of a copulatory plug. At day 17 after the last copulatory plug was observed, female mice were killed and the numbers of corpora lutea, live fetuses and resorption sites were counted.

\section{Oestrous cyclicity}

Most of the female mice (TG and WT) in the fertility study were cyclic at the time of exposure to males; however, transgenic females remated several times and had lower pregnancy rates. In an attempt to determine whether heterologous $\mathrm{GH}$ induced any alterations in the oestrous cycle, oestrous cycles were monitored over a 2 week period. At weaning, 36 transgenic and 13 wild-type female mice were allocated to one of four treatment groups: (i) transgenic female mice that received zinc supplementation from 3 to 10 weeks of age (TG ON), (ii) non-induced transgenic female mice (TG OFF), (iii) transgenic female mice that received zinc supplementation from 3 to 8 weeks of age (TG ON/OFF), and (iv) control mice that received zinc supplementation from 3 to 8 weeks of age (WT). From 8 to 10 weeks of age, female mice from all groups were subjected to vaginal saline lavage each day to assess oestrous cyclicity. The types of cell observed and estimated stage of the oestrous cycle were recorded each day for all animals.

\section{Corticosterone concentrations}

At weaning, 221 transgenic and 68 wild-type mice were allocated to one of four treatment groups: (i) transgenic female mice that received the zinc stimulus from 3 weeks of age to completion of the experiment (TG ON), (ii) noninduced transgenic female mice (TG OFF), (iii) TG female mice that received zinc supplementation from 3 to 8 weeks of age (TG ON/OFF), and (iv) control mice that received zinc supplementation from 3 to 8 weeks of age (WT). 
A subset of female mice from each treatment group was killed each day between 8:00 and 8:30 h for 8 days beginning at 8 weeks of age (day 0 ). This time frame was chosen because the TG ON/OFF female mice used in the fertility study showed an interval of approximately 8 days before pregnancy was established after initial housing with males. Animals were housed in groups of 1-2 per cage and were decapitated within $1 \mathrm{~min}$ of initial disturbance of the cage. Blood was collected directly into funnels draining into ice-cold EDTA tubes (Fisher, Santa Clara, CA). Blood was centrifuged at $2500 \mathrm{~g}$ for $30 \mathrm{~min}$, and plasma was collected and stored at $-70^{\circ} \mathrm{C}$ until assayed. Corticosterone concentrations were measured by radioimmunoassay using 125 | (ICN Pharmaceuticals, Costa Mesa, CA). Five assays were required to evaluate all the plasma samples. Treatment and day samples were assigned randomly to different assays. The intra-assay and interassay coefficients of variation were $4.45 \%$ and $10.30 \%$, respectively. The detection limit of the assay was $28.65 \mathrm{ng} \mathrm{ml}^{-1}$.

\section{Statistical analysis}

For analyses and interpretation of the results, genotypes were considered as combinations of the presence or absence of the oMt1a-oGH transgene and the provision or lack of zinc supplementation in the fertility study. Fertility (percentage of pregnant females), fecundity traits and all other data (body weights, ovulation rate, number of live pups and resorptions) were analysed by least-squares analyses of variance procedures for unequal subclass numbers using PROC GLM of SAS (SAS). The percentage of pregnant mice was also subjected to Duncan's multiplerange test (SAS). Maintenance of pregnancy was defined as a female having at least one live pup at day 17 of gestation (Murray and Pomp, 1995; Pomp et al., 1995). Days to pregnancy was defined as the number of days from the initial housing with the male until observation of a copulatory plug resulting in pregnancy. Corticosterone concentration results were evaluated by ANOVA using PROC GLM of SAS (SAS).

Fecundity traits have been defined by Murray and Pomp (1995) as: ovulation rate $(\mathrm{OR})=$ number of corpora lutea; litter size $(\mathrm{LS})=$ number of live fetuses at day 17; per cent overall embryonic survival $=($ LS/OR $)(100)$; per cent pre-implantation embryonic survival $=($ implantation sites/OR $)(100)$ and per cent post-implantation embryonic survival $=(\mathrm{LS} /$ total implantation sites)(100). The duration of the oestrous cycle was designated as the interval between two periods of prooestrus, punctuated by a period of dioestrus. Pro-oestrus was determined by the presence of epithelial cells, and dioestrus by the presence of leucocytes in the vaginal smear.

\section{Results}

\section{Fertility study}

Growth. The increase in body weight at 3-8 weeks of age did not differ between TG ON and TG ON/OFF female

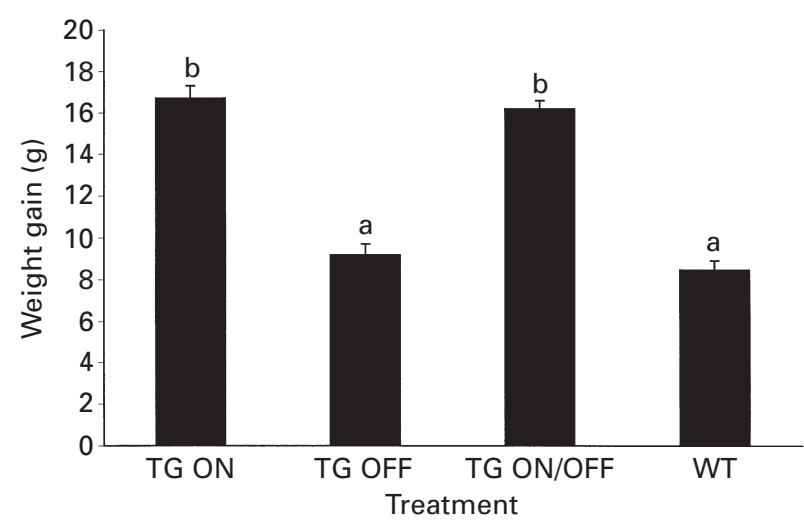

Fig. 1. Body weight gains from 3 to 8 weeks of age in chronically activated oMt1a-oGH transgenic female mice (TG ON), noninduced transgenic female mice (TG OFF), transgenic female mice inactivated at 8 weeks of age (TG ON/OFF) and wild-type control mice (WT). Values are means \pm SEM. Bars with different letters are significantly different $(P<0.05)$.

mice (Fig. 1). However, an increase in body weight was significantly less $(P<0.05)$ for WT and TG OFF mice than for the other transgenic groups (Fig. 1).

Reproductive traits. TG OFF and WT control mice did not differ from each other in reproductive traits. Pregnancy rate was determined among female mice that were observed to have mated at least once. Female mice in which a copulatory plug was not recorded but were pregnant were not used in any of the reproductive analyses. The percentage of pregnant mice for both TG ON and TG ON/OFF female mice was significantly lower $(P<0.05)$ than for TG OFF and WT mice (Table 1).

In the overall ANOVA, time to the first copulatory plug was significantly affected by treatment. However, the experimental design requires multiple comparisons of the four treatment groups and this dictates the use of more conservative type I error values, such as those used by the Bonferroni adjustment. In the face of the multiple comparisons, significant differences between treatment effects disappear thereby precluding a ranking of time to copulatory plug by treatment group (Table 1 ). Inactivation of the transgene increased the incidence of remating leading to a longer interval to pregnancy in TG ON/OFF female mice compared with all other treatment groups $(P<0.05)$ (Table 1$)$. TG ON, TG OFF and WT mice that became pregnant did so within the first 3 days of introduction to males (Table 1). Of the 18 mice that became pregnant in the TG ON/OFF group, nine mice became pregnant after the second copulatory plug was observed, and one female after the third copulatory plug (data not shown).

Both TG ON and TG ON/OFF mice had two to three additional ovulations $(P<0.05)$ compared with either WT control or TG OFF mice (Table 1). The TG ON female mice tended to produce these 'extra' ovulations on the right ovary 
Table 1. Reproductive data for oMt1a-oGH transgenic and wild-type female mice

\begin{tabular}{|c|c|c|c|c|c|c|c|}
\hline Treatment & $\begin{array}{l}\text { Females } \\
\text { mated }^{1}\end{array}$ & $\begin{array}{c}\text { Females } \\
\text { pregnant }^{2}\end{array}$ & Pregnant (\%) & $\begin{array}{c}\text { Days to first } \\
\text { copulatory plug }\end{array}$ & $\begin{array}{l}\text { Interval to } \\
\text { pregnancy }\end{array}$ & $\begin{array}{l}\text { Ovulation } \\
\text { rate }^{5}\end{array}$ & Live fetuses $^{6}$ \\
\hline TG ON & 14 & 3 & $21.4^{\mathrm{a}}$ & $2.33 \pm 1.17$ & $2.33 \pm 1.17^{a}$ & $11.67 \pm 0.87^{b}$ & $10.33 \pm 0.98$ \\
\hline TG OFF & 15 & 14 & $93.3^{c}$ & $2.57 \pm 0.54$ & $2.86 \pm 0.66^{a}$ & $8.57 \pm 0.40^{\mathrm{a}}$ & $7.92 \pm 0.45$ \\
\hline TG ON/OFF & 30 & 18 & $60.0^{b}$ & $4.28 \pm 0.48$ & $7.89 \pm 0.58^{b}$ & $10.83 \pm 0.35^{\mathrm{b}}$ & $8.72 \pm 0.40$ \\
\hline WT & 22 & 22 & $100.0^{c}$ & $2.50 \pm 0.43$ & $2.50 \pm 0.43^{a}$ & $8.86 \pm 0.32^{\mathrm{a}}$ & $7.64 \pm 0.36$ \\
\hline
\end{tabular}

Values are mean \pm SEM.

Values with different superscripts within each column are significantly different $(P<0.05)$.

TG ON: chronically induced transgenic female mice; TG OFF: non-induced transgenic female mice; TG ON/OFF: transgenic female mice inactivated at 8 weeks of age; WT: wild-type control mice.

${ }^{1}$ Number of females having exhibited at least one copulatory plug.

2Percentage of pregnant females shown to have mated.

${ }^{3}$ Days from initial housing with male to observation of the first copulatory plug.

${ }^{4}$ Days from initial housing with male to observation of copulatory plug resulting in pregnancy.

${ }^{5}$ Number of corpora lutea at day 17 of pregnancy.

${ }^{6}$ Number of live fetuses at day 17 of pregnancy.

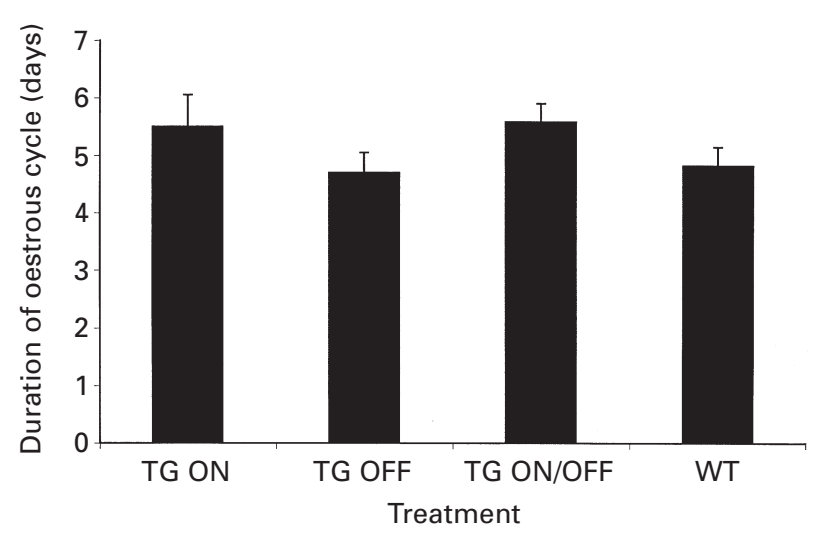

Fig. 2. Duration of the oestrous cycle as assessed by vaginal lavage for chronically induced oMt1a-oGH transgenic female mice (TG $\mathrm{ON}$ ), non-induced transgenic female mice (TG OFF), transgenic female mice inactivated at 8 weeks of age (TG ON/OFF) and wildtype (WT) control mice.

(data not shown). Although the treatment group was a significant determinant of number of fetuses produced at day 17 , the variation within a group did not allow statistical ranking of the groups (Table 1). Resorption rates did not differ among groups. Overall embryonic survival, preimplantation embryonic survival, and post-implantation embryonic survival did not differ among groups: $87.2 \%$, $94.7 \%$ and $92.1 \%$, respectively.

\section{Oestrous cyclicity study}

The duration of the oestrous cycle did not differ among the treatment groups (Fig. 2). In a number of vaginal smears collected from mice, leukocytes, epithelial and cornified cells were all present. This finding was displayed by a subset of mice in all treatment groups and at times, mice would remain at this stage for several days (data not shown).

\section{Corticosterone concentrations}

Treatment was a significant determinant of plasma corticosterone concentrations. Corticosterone concentrations were higher $(P<0.0001)$ in TG ON and TG ON/OFF female mice than in TG OFF and WT mice (Fig. 3). Plasma corticosterone was also significantly higher in TG OFF mice than in WT mice $(P<0.0001)$ (Fig. 3). Plasma corticosterone concentrations by treatment and day are shown (Table 2).

\section{Discussion}

The purpose of this study was to evaluate the effects of heterologous $\mathrm{GH}$ on the reproductive function of transgenic mice. The present study extends previous work on oMt1a$\mathrm{oGH}$ transgenic mice by showing that reduced incidence of pregnancy in TG ON mice was not due to an alteration in oestrous cyclicity, and that transgene inactivation resulted in an increase in pregnancy rate relative to TG ON female mice. $\mathrm{GH}$ either directly or more likely through the associated increase in plasma corticosterone interferes with the establishment and maintenance of pregnancy.

Although TG ON and TG ON/OFF mice did not display an extended oestrous cycle, as reported in other $\mathrm{GH}$ transgenic mouse lines (Bartke et al., 1988; Cecim et al., 1995b, c), it is possible that the level of regulation of transgene expression (that is, the 'leakiness' of the promoter) may affect the duration of the oestrous cycle. Although the oMt1a promoter conveys fairly tight regulation of transgene expression (Shanahan et al., 1989), constructs using a mouse MT promoter show constitutive overexpression of $\mathrm{GH}$ even in the absence of heavy-metal induction (Palmiter et al., 1983; Orian et al., 1989). Therefore, although the oMt1a-oGH mice display increased concentrations of $\mathrm{GH}$ for only a limited period during development, other transgenic $\mathrm{GH}$ mouse lines experience heterologous GH prenatally (Palmiter et al., 1983). This prolonged and increased expression of $\mathrm{GH}$ may contribute to extended oestrous cycles. 


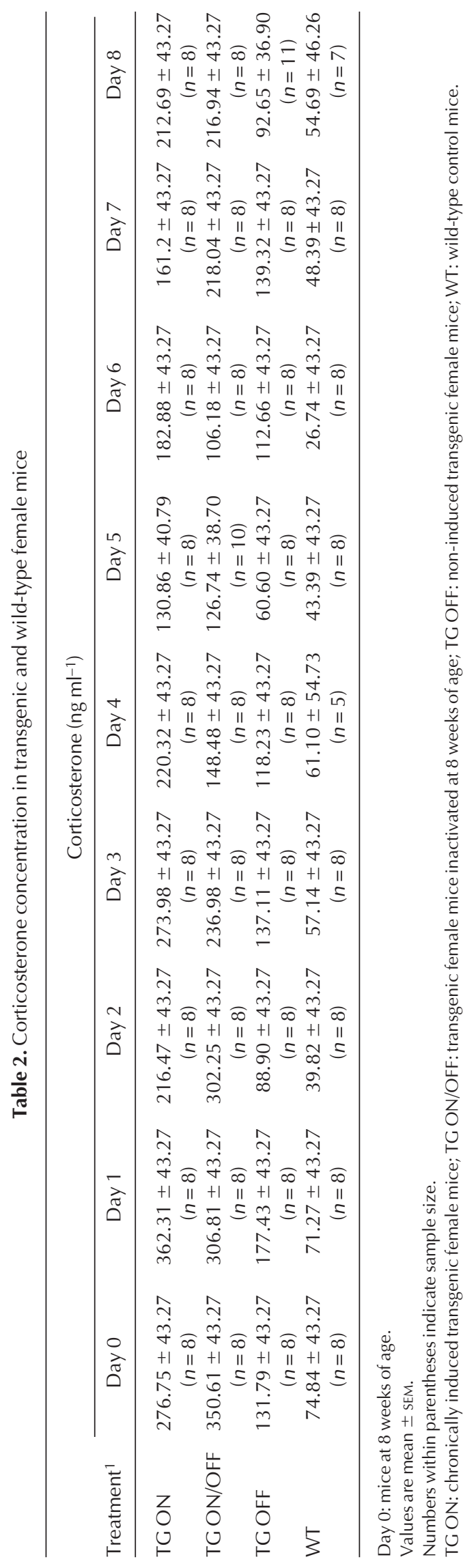




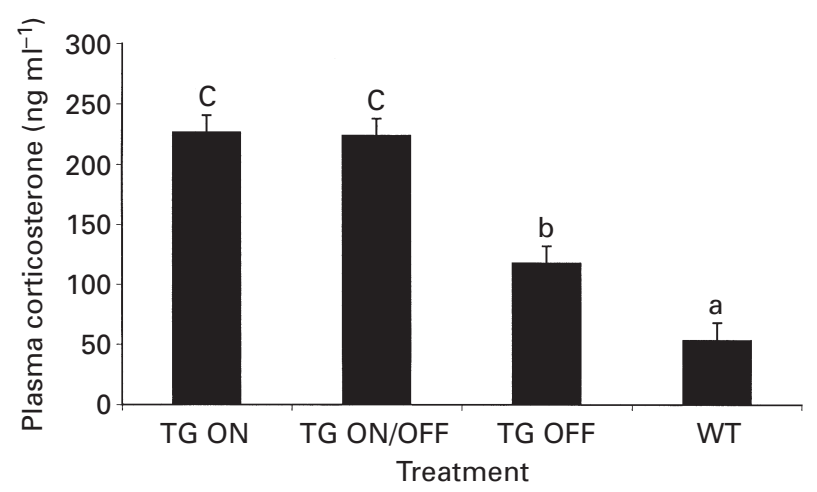

Fig. 3. Plasma concentrations of corticosterone from day 0 to day 8 for chronically induced oMt1a-oGH transgenic female mice (TG ON), non-induced transgenic female mice (TG OFF), transgenic female mice inactivated at 8 weeks of age (TG ON/OFF) and wildtype (WT) control mice. Values are means \pm sem. Bars with different letters are significantly different $(P<0.0001)$.

In addition, cytology of vaginal lavage showed multiple types of cell in mice of different genotypes. In mice that showed this cell distribution for several days, the proportion of each type of cell usually changed each day. It is possible that the heterologous $\mathrm{GH}$ may have contributed to this unique pattern of cells; however, a similar distribution of cells was observed in a number of wild-type animals, leading to the conclusion that it was a line effect of the mice used in this study.

Low pregnancy rates have been observed in a variety of $\mathrm{GH}$ transgenic mouse lines (Bartke et al., 1988; Cecim et al., 1995b; Murray and Pomp, 1995). Murray and Pomp (1995) demonstrated that chronic expression of the oGH transgene resulted in reduced pregnancy rates, despite the presence of blastocysts on day 3 of pregnancy and, therefore, concluded that lack of pregnancy was due to implantation failure. Embryonic survival rate in the present study indicates that once pregnancy is established, gestation appears to proceed normally. This finding is in contrast to reports on other $\mathrm{GH}$ transgenic mouse lines, in which a high incidence of post-implantation embryonic loss was reported (Naar et al., 1991). Increased corticosterone secretion associated with transgene expression was also observed, confirming reports in other $\mathrm{GH}$ transgenic mouse lines (Cecim et al., 1991, 1996). Chronically high concentrations of corticosterone interfere with implantation (Spaziani and Szego 1958; Schlough 1971). Corticosterone treatment inhibits the increase in capillary permeability in the uterus that is necessary for implantation to occur (Spaziani and Szego 1958; Schlough 1971), and Wong and Burton (1973) observed that the mouse placenta binds both progestins and corticoids in a competitive manner. Ogle (1974) hypothesized that in deermice increased corticosteroid production results in pregnancy loss due to increased binding by the uterine and placental receptors of corticoids at the expense of progesterone. In support of this finding, Pomp et al. (1995) found that administration of progesterone up to day 17 of gestation was necessary for oMt1a-oGH female mice to maintain pregnancy.

Adrenal progesterone contributes to the maternal pool of progesterone in rats (MacDonald and Matt, 1984). Fajer et al. (1971) observed that corticosterone secretion was markedly increased at the expense of progesterone in stressed rats. MacNiven and de Catanzaro (1990) reported that stress early in gestation resulted in the loss of pregnancy, although pregnancy could be rescued with progesterone or metyrapone, an inhibitor of adrenal 11 -hydroxylase. MacNiven and de Catanzaro (1990) hypothesized that the reduction in available progesterone, attributable to increased corticosterone secretion associated with stress, was unable to sustain pregnancy. This suppression of progesterone may alter the progesterone:oestrogen ratio, which is important for implantation. Studies in both humans (GidleyBaird et al., 1986) and mice (Humphrey, 1968) have demonstrated that oestrogen dominance around the time of implantation reduces the incidence of pregnancy. Because of the variation in circulating corticosterone observed within treatment groups, TG ON and TG ON/OFF female mice that were able to establish and maintain pregnancy may have been able to do so because their individual corticosterone concentrations were low enough not to affect the progesterone:oestrogen ratio. Approximately $38 \%$ of TG ON and $74 \%$ of TG ON/OFF mice assessed for glucocorticoids had corticosterone concentrations within the range of those observed in wild-type mice, in which no impairment of fertility has been observed.

The extended interval to establish pregnancy in TG ON/OFF female mice was due to an increased incidence of remating, which is possibly the result of a combination of reduced circulating $\mathrm{GH}$ and increased corticosterone secretion. Presumably, increased corticosterone secretion is a result of direct or indirect actions of heterologous $\mathrm{GH}$ at one or more levels of the hypothalamic-pituitary-adrenal axis (Cecim et al., 1991). It is unclear how transgene inactivation improves pregnancy rates. Although $\mathrm{GH}$ concentrations are markedly reduced within $24 \mathrm{~h}$ of transgene inactivation (Shanahan et al., 1989), this time frame is insufficient to improve reproductive performance markedly. Heterologous GH attenuates GnRH-induced LH secretion (Chandrashekar et al., 1988; Tang et al., 1993), and it is possible that gonadotrophin secretion takes more than $24 \mathrm{~h}$ to return to normal concentrations after transgene inactivation. In contention with this finding is the apparent normal gonadotrophin function associated with ovulation. Alternatively, prolactin secretion induced by mating may be insufficient to maintain the corpus luteum. However, Pomp et al. (1995) reported that prolactin supplementation failed to rescue pregnancy in oMt1a-oGH mice. It is likely that in animals expressing the $\mathrm{oGH}$ transgene the associated increase in plasma corticosterone results in implantation failure due to inadequate progesterone secretion and consequently female mice continue to cycle and mate until pregnancy is established. 
Increased concentrations of corticosterone may also contribute to leptin resistance, which has been associated with impaired fertility. Dexamethasone, a synthetic glucocorticoid, upregulates leptin gene expression both in vitro (Murakami et al., 1995; Slieker et al., 1996) and in vivo (de Vos et al., 1995), and may contribute to a condition of leptin resistance. Previous work from our laboratory has confirmed leptin resistance in TG ON/OFF mice (Runstadler et al., 2001). Dexamethasone administration leads to an increase in hypothalamic expression of neuropeptide $Y$ in the arcuate nucleus (Wilding et al., 1993). During a normal oestrous cycle, high neuropeptide $\mathrm{Y}$ expression is necessary for the pro-oestrus LH surge to occur (Kalra, 1993). However, chronically high expression of neuropeptide $Y$ is associated with infertility (Catzeflis et al., 1993; Pierroz et al., 1995). Thus, in a leptin-resistant state potentiated by glucocorticoids, it is likely that leptin is less able to downregulate neuropeptide $Y$ expression, resulting in suppression of GnRH (Pierroz et al., 1995) and subsequent reduction in fertility. In contention with this theory is the increased number of ova shed spontaneously in both the TG ON and TG ON/OFF mice, which would indicate normal function of both $\mathrm{LH}$ and $\mathrm{FSH}$, at least in transgenic animals that were able to establish and maintain pregnancy.

The present study reported an increased ovulation rate for oMt1a-oGH mice expressing the transgene, as has been observed in this (Murray and Pomp, 1995; Pomp et al., 1995) and other GH lines (Naar et al., 1991). It is unclear whether $\mathrm{GH}$ exerts its effects on ovulation through hepatic IGF-I, acting on the ovary directly or through local ovarian production of IGF-I, which amplifies ovarian responsiveness to gonadotrophins (Geisthovel et al., 1990). IGF-I synergizes with FSH to stimulate aromatase activity (Adashi et al., 1985a,b; Erickson et al., 1989), which results in increased oestradiol production important for ovulation (Ando et al., 1994).

Although chronic expression of the transgene suppresses fertility, withdrawal of the transgene stimulus significantly increases pregnancy rates in TG ON/OFF mice, reflecting the ability of reproductive function to improve after transgene inactivation. In conclusion, increased corticosterone secretion, associated with transgene expression, impairs fertility by interfering with implantation, resulting in repeated matings until implantation can be established. In addition, corticosterone may induce leptin resistance, which can also impair fertility. Further study is required to assess progesterone and oestrogen concentrations after mating to validate implantation failure due to reduced progesterone secretion. Studies are currently being undertaken to correlate leptin resistance with transgene expression and fertility.

\section{References}

Adashi EY, Resnick CE, D'Ercole AJ, Svoboda ME and Van Wyk JJ (1985a) Insulin-like growth factors as intraovarian regulators of granulose cell growth and function Endocrine Review 6 400-420

Adashi EY, Resnick CE, Brodie AMH, Svoboda ME and Van Wyk JJ (1985b)
Somatomedin-C-mediated potentiation of follicle-stimulating hormoneinduced aromatase activity of cultured rat granulosa cells Endocrinology 117 2313-2320

Ando M, Yoshimur Y, Iwashita M, Oda T, Karube M, Ubukata Y, Jinno $M$ and Nakamura $Y$ (1994) Direct ovarian effect of growth hormone in the rabbit American Journal of Reproductive Immunology 31 123-132

Baldwin DM (1979) The effect of glucocorticoids on estrogen-dependent luteinizing hormone release in the ovariectomized rat and on gonadotropin secretion in the intact female rat Endocrinology 105 120-128

Bartke A, Steger RW, Hodges SL, Parkening TA, Collins TJ, Yun JS and Wagner TE (1988) Infertility in transgenic female mice with human growth hormone expression: evidence for luteal failure Journal of Experimental Zoology 248 121-124

Brann DW and Mahesh VB (1991) Role of corticosteroids in female reproduction FASEB Journal 5 2691-2698

Buskirk DD, Faulkner DB, Hurley WL, Kesler DJ, Ireland FA, Nash TG, Castree JC and Vicini JL (1996) Growth, reproductive performance, mammary development and milk production of beef heifers as infuenced by prepubertal dietary energy and administration of bovine somatotropin Journal of Animal Science 74 2649-2662

Campbell RG, Steele NC, Caperna TJ, McMurtry JP, Solomon MB and Mitchell AD (1989) Interrelationships between sex and exogenous growth hormone administration on performance, body composition and protein and fat accretion of growing pigs Journal of Animal Science $\mathbf{6 7}$ 177-186

Catzeflis C, Pierroz DD, Rohner-Jeanrenaud F, Rivier JE, Sizonenko PC and Aubert ML (1993) Neuropeptide $Y$ administered chronically into the lateral ventricle profoundly inhibits both the gonadotropic and the somatotropic axis in intact adult female rats Endocrinology 132 224-234

Cecim M, Ghosh PK, Esquifino AI, Began T, Wagner TE, Yun JS and Bartke A (1991) Elevated corticosterone levels in transgenic mice expressing human or bovine growth hormone genes Neuroendocrinology $\mathbf{5 3}$ 313-316

Cecim M, Fadden C, Kerr J, Steger RW and Bartke A (1995a) Infertility in transgenic mice overexpressing the bovine growth hormone gene: disruption of the neuroendocrine control of prolactin secretion during pregnancy Biology of Reproduction 52 1187-1192

Cecim M, Kerr J and Bartke A (1995b) Effects of bovine growth hormone $(\mathrm{bGH})$ transgene expression or bGH treatment on reproductive functions in female mice Biology of Reproduction 52 1144-1148

Cecim M, Kerr J and Bartke A (1995c) Infertility in transgenic mice overexpressing the bovine growth hormone gene: luteal failure secondary to prolactin deficiency Biology of Reproduction 52 1162-1166

Cecim M, Alvarez-Sanz M, van de Kar L, Milton S and Bartke A (1996) Increased plasma corticosterone levels in bovine growth hormone $(\mathrm{bGH})$ transgenic mice: effects of $\mathrm{ACTH}, \mathrm{GH}$ and IGF-1 on in vitro adrenal corticosterone production Transgenic Research 5 187-192

Chandrashekar V, Bartke A and Wagner TE (1988) Endogenous human growth hormone $(\mathrm{GH})$ modulates the effect of gonadotropin-releasing hormone on pituitary function and the gonadotropin response to the negative feedback effect of testosterone in adult male transgenic mice bearing the human GH gene Endocrinology 123 2717-2722

Chapula W and Galligan DT (1989) Nutritional implications of somatotropin for lactating cows Journal of Dairy Science 72 2510-2524

Chapula W, Vechiarelli B, Galligan DT et al. (1996) Responses of dairy cows supplemented with somatotropin during weeks 5 through 43 of lactation Journal of Dairy Science 79 800-812

de Catanzaro D (1987) Alteration of estrogen-induced lordosis through central administration of corticosterone in adrenalectomized-ovariectomized rats Neuroendocrinology 46 468-474

de Catanzaro D and Gorzalka BB (1980) Effects of dexamethasone, corticosterone, and ACTH on lordosis in ovariectomized and adrenalectomized-ovariectomized rats Pharmacology Biochemistry and Behavior 12 201-206

de Catanzaro D, Gray DS and Gorzalka BB (1981a) Effects of acute central and peripheral ACTH administration on lordosis behavior Physiology and Behavior 26 207-213 
de Catanzaro D, Knipping RP and Gorzalka BB (1981b) Antagonism of estrogen-induced lordosis by corticosterone in adrenalectomizedovariectomized female rats and mice Pharmacology Biochemistry and Behavior 15 761-766

de Vos P, Saladin R, Auwerx J and Staels B (1995) Induction of ob gene expression by corticosteroids is accompanied by body weight loss and reduced food intake Journal of Biological Chemistry 27015 958-15961

Downer JV, Patterson DL, Rock DW et al. (1993) Dose titration of sustained-release recombinant bovine somatotropin in lactating dairy cows Journal of Dairy Science 76 1125-1136

Erickson GF, Garzo G and Magoffin DA (1989) Insulin-like growth factor-I regulates aromatase activity in human granulosa and granulosa lutein cells Journal of Clinical Endocrinology and Metabolism 69 716-724

Esteban E, Kass PH, Weaver LD, Rowe JD, Holmber CA, Franti CE and Troutt HF (1994) Reproductive performance in high producing dairy cows treated with recombinant bovine somatotropin Journal of Dairy Science 77 3371-3381

Etherton TK, Wiggins JP, Chung CS, Evock CM, Rebhun JF and Walton PE (1986) Stimulation of pig growth performance by porcine growth hormone and growth hormone-releasing factor Journal of Animal Science 63 1389-1399

Fajer AB, Holzbauer $\mathbf{M}$ and Newport HM (1971) The contribution of the adrenal gland to the total amount of progesterone produced in the female rat Journal of Physiology 214 115-126

Geisthovel F, Moretti-Rojas I, Rojas FJ and Asch RH (1990) Insulin-like growth factors and thecal-granulosa-cell function Human Reproduction $5785-799$

Gidley-Baird AA, O'Neill C, Sinosich MJ, Porter RN, Pike IL and Saunders DM (1986) Failure of implantation in human in vitro fertilization and embryo transfer patients: the effects of altered progesterone/estrogen ratios in humans and mice Fertility and Sterility 45 69-74

Humphrey KW (1968) The effects of some anti-oestrogens on the deciduoma reaction and delayed implantation in the mouse Journal of Reproduction and Fertility 16 201-209

Jadresic A, Banks LM, Ghild DF, Diamant L, Doyle FH, Fraser TR and Joplin GF (1982) The acromegaly syndrome Quarterly Journal of Medicine 202 189-204

Kalra SP (1993) Mandatory neuropeptide-steroid signaling for the preovulatory luteinizing hormone-releasing hormone discharge Endocrine Reviews 14 507-538

Kamel F and Kubajak CL (1987) Modulation of gonadotropin secretion by corticosterone: interaction with gonadal steroids and mechanism of action Endocrinology 121 561-568

MacDonald GJ and Matt DW (1984) Adrenal and placental steroid secretion during pregnancy in the rat Endocrinology $1142068-2073$

MacNiven E and de Catanzaro D (1990) Reversal of stress-induced pregnancy blocks in mice by progesterone and metyrapone Physiology and Behavior 47 443-448

McGuffey RK, Basson RP and Spike TE (1991a) Lactation response and body composition of cows receiving somatotropin and three ratios of forage to concentrate Journal of Dairy Science 74 3095-3102

McGuffey RK, Basson RP, Snyder DL, Block E, Harrison JH, Rakes AH, Emery RS and Muller LD (1991b) Effect of somidobove sustained release administration on the lactation performance of dairy cows Journal of Dairy Science 74 1263-1276

Murakami T, lida M and Shima K (1995) Dexamethasone regulates obese expression in isolated rat adipocytes Biochemical and Biophysical Research Communications 214 1260-1267

Murray JD and Pomp D (1995) Interaction between reproductive performance and dietary energy levels fed to female oMt1a-oGH transgenic mice Transgenics 1 553-563

Naar EM, Bartke A, Majumdar SS, Buonomo FC, Yun JS and Wagner TE (1991) Fertility of transgenic female mice expressing bovine growth hormone or human growth hormone variant genes Biology of Reproduction 45 178-187
Oberbauer AM, Stern JS, Johnson PR, Horowitz BA, German JB, Phinney SD, Beermann DH, Pomp D and Murray JD (1997) Body composition of inactivated growth hormone (oMt1a-oGH) transgenic mice: generation of an obese phenotype Growth, Development and Aging 61 169-179

Oberbauer AM, Runstadler JA, Havel PJ and Murray JD (2001) Obesity and elevated plasma leptin concentration in oMt1a-oGrowth hormone transgenic mice Obesity Research 9 51-58

Ogle TF (1974) Effects of ACTH on ovarian histochemistry and maintenance of pregnancy in deermice Biology of Reproduction 11 288-296

Oldenbroek JK, Garssen GJ, Jonker LJ and Wilkinson JID (1993) Effects of treatment of dairy cows with recombinant bovine somatotropin over three or four lactations Journal of Dairy Science 76 453-467

Orian JM, Lee CS, Weiss LM and Brandon MR (1989) The expression of a metallothionein-ovine growth hormone fusion gene in transgenic mice does not impair fertility but results in pathological lesions in the liver Endocrinology 124 455-463

Palmiter RD, Norstedt G, Gelinas RE, Hammer RE and Brinster RL (1983) Metallothionein-human $\mathrm{GH}$ fusion genes stimulate growth of mice Science 222 809-814

Pierroz DD, Gruaz NM, d'Allèves V and Aubert ML (1995) Chronic administration of neuropeptide $\mathrm{Y}$ into the lateral ventricle starting at 30 days of life delays sexual maturation in the female rat Neuroendocrinology 61 293-300

Pomp D, Geisert RD, Durham CM and Murray JD (1995) Rescue of pregnancy and maintenance of corpora lutea in infertile transgenic mice expressing an ovine metallothionein 1a-ovine growth hormone fusion gene Biology of Reproduction 51 170-178

SAS (1988) SAS/STAT User's Guide, Release 6.03 Statistical Analysis System Institute, Inc., North Carolina

Schlough JS (1971) The effect of glucocorticoids on preimplantation capillary permeability in the rat Fertility and Sterility 22 389-391

Shanahan CM, Rigby NW, Murray JD, Marshall JT, Townrow CA, Nancarrow CD and Ward KA (1989) Regulation of expression of a sheep metallothionein 1a-sheep growth hormone fusion gene in transgenic mice Molecular and Cellular Biology 9 5473-5479

Slieker LJ, Sloop KW, Surface PL, Kriauciunas A, LaQuier F, Manetta J, BueValleskey J and Stephens TW (1996) Regulation of expression of $o b$ mRNA and protein by glucocorticoids and cAMP Journal of Biological Chemistry 271 5301-5304

Spaziani E and Szego CM (1958) The influence of estradiol and cortisol on uterine histamine of the ovariectomized rat Endocrinology 63 669-678

Stelwagen K, Grieve DG, Walton JS, Ball JL and McBride BW (1993) Effect of prepartum bovine somatotropin in primigravid ewes on mammogenesis, milk production, and hormone concentrations Journal of Dairy Science 76 992-1001

Suter DE and Schwartz NB (1985) Effects of glucocorticoids on secretion of luteinizing hormone and follicle-stimulating hormone by female rat pituitary cells in vitro. Endocrinology 117 849-854

Tang K, Bartke A, Gardiner CS, Wagner TE and Yun JS (1993) Gonadotropin secretion, synthesis, and gene expression in two types of bovine growth hormone transgenic mice Biology of Reproduction 49 346-353

Wilding JPH, Gilbey SG, Lambert PD, Ghatei MA and Bloom SR (1993) Increases in neuropeptide $Y$ content and gene expression in the hypothalamus of rats treated with dexamethasone are prevented by insulin Neuroendocrinology 57 581-587

Wong MD and Burton AF (1973) Isolation and preliminary characterization of corticosterone-receptor complexes in mouse placental tissue Biochemical and Biophysical Research Communications 50 71-79

Received 14 March 2001.

First decision 24 April 2001.

Accepted 14 June 2001. 